\title{
PRODUCTION AND BIOACTIVITY POTENTIAL OF THREE RECOMBINANT GROWTH HORMONES OF FARMED FISH
}

\author{
Alimuddin"*\#, Indra Lesmana ${ }^{* *}$, Agus Oman Sudrajat"), Odang Carman"), and Irvan Faizal ${ }^{* * * *}$ ) \\ "Department of Aquaculture, Faculty of Fisheries and Marine Sciences, \\ Bogor Agricultural University \\ **) Master Candidate, Department of Aquaculture, Faculty of Fisheries and Marine Sciences, \\ Bogor Agricultural University \\ ${ }^{* * *}$ Agency for the Assessment and Application of Technology, \\ Ministry of Research Affairs and Technology
}

(Received 11 March 2010; Accepted 11 May 2010)

\begin{abstract}
This study was aimed to produce recombinant growth hormone ( $\mathrm{rGH}$ ) from giant grouper (Epinephelus lanceolatus), giant gouramy (Osphronemus gouramy) and common carp (Cyprinus carpio) and compare their bioactivity potential by means of inducing the growth hormone of juvenile Nile tilapia (Oreochromis niloticus) as the model. DNA fragment encoding mature $\mathrm{GH}$ protein of giant grouper $(E /-\mathrm{mGH})$, giant gouramy $(\mathrm{Og}-\mathrm{mGH})$ and common carp $(\mathrm{Cc}-\mathrm{mGH})$ was amplified by PCR method. The purified PCR products were ligated to pCold- 1 to generate $\mathrm{pCold} / \mathrm{El}-\mathrm{mGH}$, pCold/Og$\mathrm{mGH}$, and $\mathrm{pCold} / \mathrm{Cc}-\mathrm{mGH}$ protein expression vector, respectively. Each of the expression vectors was transformed into the Escherichia coli BL21. E. coli BL21 was cultured using 2 XYT medium and protein production was induced by cold shock at $15 \pm 1{ }^{\circ} \mathrm{C}$ for overnight. The inclusion bodies of $E$. coli transformants containing protein expression vector were isolated by sonication method, and $\mathrm{rGH}$ production was analyzed by SDS-PAGE. Juvenile of Nile tilapia of average body weight of $12.41 \pm 3.28 \mathrm{~g}$ was intramuscularly injected once a week for 4 weeks with $1 \mathrm{\mu g}$ inclusion body containing $\mathrm{rGH}$ per gram fish body weight. The result showed that $\mathrm{rGH}$ in molecular weight of about $25 \mathrm{kDa}$ was obtained. Fish injected with rGH of $\mathrm{El}-\mathrm{mGH}, \mathrm{Cc}-\mathrm{mGH}$ and $\mathrm{Og}$-mGH grew $20.94 \%, 18.09 \%$, and $16.99 \%$ faster, respectively, compared with the control. This result indicated that the three $\mathrm{rGH}$ produced in E. coli possessed biological activity when tested on Nile tilapia and further research is needed to find its effect on the growth of other aquaculture fish species.
\end{abstract}

KEYWORDS: bioactivity, recombinant protein, growth hormone, Nile tilapia

\section{INTRODUCTION}

Various genetic manipulation techniques have been developed to improve the growth of farmed fish such as breeding selection, protein recombination, and transgenesis. The process of selective breeding requires a relatively long time to achieve significant results be- cause the genetic gain per generation is relatively low, as reported by Bolivar \& Newkirk (2002) on selective breeding of tilapia where 12 generations were required to double the growth rate. Over-expression of growth hormone $(\mathrm{GH})$ gene using transgenesis technology can drastically improved fish growth (Nam

\# Corresponding author. Department of Aquaculture, Faculty of Fisheries and Marine Sciences, Bogor Agricultural University, Bogor 16680, West Java, Indonesia. Tel.: + 622518628755

E-mail address: alimuddin_alsani@yahoo.com 
et al., 2001; Kobayashi et al., 2007). Transgenesis needs shorter time to achieve a significant result (three generations) compared to selection method (more than three generations). However, transgenesis can only be performed on fish which their eggs can artificially be fertilized, or one cell stage embryo can be collected before gene construct is transferred.

Numerous studies have demonstrated that injection of native or recombinant $\mathrm{GH}(\mathrm{rGH})$ to different fish species resulted in growth enhancement (Funkenstein, 2006), indicating that increased levels of $\mathrm{GH}$ have the potential to improve growth of fish. GH can also be administered to fish by oral (Moriyama et al., 1993; Tsai et al., 1997, Jeh et al., 1998) and immersion method (Moriyama \& Kawauchi, 1990). Enhancement of growth on several fish species after $\mathrm{rGH}$ protein administration had been reported such as rainbow trout (Onchorhynchus mykiss) using salmon rGH (Moriyama et al., 1993), Japanese flounder (Paralichtys olivaceus) using flounder rGH (Jeh et al., 1998) and common carp using giant catfish (Pangasianodon gigas) rGH (Promdonkoy et al., 2004).

In this study, we designed three protein expression vectors producing rGH by Escherichia coli and then analyzed their bioactivity by injecting them in juvenile of Nile tilapia as the model. This study is a first step to find an alternative way in order to increase the growth rate of farmed fish in Indonesia to support the Ministry of Marine Affairs and Fisheries aquaculture production target on 2014.

\section{MATERIALS AND METHODS}

\section{Fish Maintanance}

Juveniles of Nile tilapia (average body weight of $12.41 \pm 3.28 \mathrm{~g}$ ) were obtained from Freshwater Aquaculture Research Center, Bogor. They were maintained in indoor aquaria $(90 \mathrm{~L})$ under natural photoperiod and fed with a commercial diet to satiation three times daily. Water exchange of fish rearing media was $50 \%$ of the total volume conducted every day before feeding was performed.

\section{Construction of Protein Expression Vector}

DNA fragments coding for signal peptide and mature $\mathrm{GH}$ protein $(\mathrm{mGH})$ was predicted by using SignalP 3.0 software (http://cbs.dtu.dk/
services/signalP). mGH DNA fragment was amplified by PCR with a template of plasmid containing the full-length of $\mathrm{GH}$ cDNA from giant gouramy (Nugroho et al., 2008), giant grouper (Mulyadi et al., 2008) and common carp (Alimuddin, unpublished) using a set of primer for each species. Primer sets for giant grouper $\mathrm{mGH}(\mathrm{El}-\mathrm{mGH}) \mathrm{DNA}$ fragment amplification were $\mathrm{El}$-mGH-F (5' -ctcgag cag cca atc aca gac ggc cag-3') and El-mGH-R (5'-aagctt cta cag ggt aca gtt gge ctc agg-3') containing Xho I and Hind III recognition sites (underlined) respectively. Primer sets for giant grouper $\mathrm{mGH}(\mathrm{Og}-\mathrm{mGH})$ were $\mathrm{Og}$ - $\mathrm{mGH}-\mathrm{F}$ (5'- ggatcc cag cca atc aca gac agc cag-3') and $\mathrm{Og}$-mGH-R (5'-gaattc cta cag agt gca gtt agc ttc tgg-3'), containing $\mathrm{Bam} \mathrm{HI}$ and Eco RI recognition sites (underlined) respectively. Further, primers for amplification of common carp mGH (Cc-mGH) DNA fragment were $\mathrm{Cc}-\mathrm{mGH}-\mathrm{F}$ (5'-ggatcc tca gac aac cag cgg ctc ttc-3') and Cc-mGH-R (5'-gtcgac cta cag ggt gca gtt gga atc cag-3') containing Bam $\mathrm{HI}$ and Sal I recognition sites (underlined), respectively. The PCR products were purified, cloned into the pGEM-T Easy vector (Promega), and used for DNA sequencing. DNA sequencing was carried out using ABI PRISM ${ }^{\circledR}$ 3100-Avant Genetic Analyzer following the manufacturer's protocols.

Plasmid pGEM-T Easy containing the $\mathrm{mGH}$ DNA fragment was digested with two restriction enzymes as described in the cloning of each fish $\mathrm{mGH}$ above. The $\mathrm{mGH}$ fragment was ligated into the corresponding sites of the expression vector pCold-1 (4.4 kb; Takara) controlled by cspA promoter. The plasmid construct was designated as pCold/El-mGH, pCold/ Cc-mGH and pCold/Og-mGH for giant grouper, common carp and giant gouramy mGHs, respectively.

\section{Production and Bioactivity Analysis of $\mathrm{rGH}$ Protein}

E. coli BL21 (DE3) harboring pCold/El-mGH, pCold/Cc-mGH, or pCold/Og-mGH was incubated at $15^{\circ} \mathrm{C}$ for 24 hours in a $2 \times Y T$ medium (Alimuddin et al., 2008) containing $100 \mu \mathrm{g}$ of ampicillin per $\mathrm{mL}$ and $1 \mathrm{mM} \mathrm{IPTG} \mathrm{(isopropyl-b-D-}$ thiogalactopyranoside) for induction of protein synthesis. The bacterial cells were harvested by centrifugation for $5 \mathrm{~min}$ at 13,000 rpm in a refrigerated centrifuge, resuspended in phosphate buffer saline (PBS), washed twice by the same solution, sonicated twice for $30 \mathrm{~s}$ on ice, centrifuged again and the resultant pellet of 
inclusion bodies was resuspended in PBS containing SDS and $\beta$-mercaptoethanol. Sample were heated at $100^{\circ} \mathrm{C}$ for $5 \mathrm{~min}$, chilled on ice and then centrifuged briefly. An aliquot of 10 $\mu \mathrm{L}$ was analyzed by SDS-PAGE with a concentration of $10 \%$ polyacrylamide gel, and protein was visualized using Coomassie Blue dye.

A total of 100 Nile tilapia juveniles were randomly divided into five groups with $20 \mathrm{ju}$ veniles per group. The juvenile in each group were stocked in the two separate aquaria. Three fish groups were intramuscularly injected once a week for 4 weeks with $1 \mu \mathrm{g}$ inclusion body containing $\mathrm{rGH}$ per gram fish body weight. The inclusion body was dissolved in phosphate buffer saline (PBS). The last two groups were as controls, i.e. first fish groups was injected with inclusion body from bacteria harboring pCold 1-empty without insertion of mGH DNA fragment, and the second was injected with an equal volume of PBS. The juvenile were fed with commercial diet three times daily at satiation. Feeding and water management were the same for all treatments. Individual body weight was measured every week for 2 months. Data obtained were descriptively analyzed.

\section{RESULTS AND DISCUSSION}

\section{Construction of Protein Expression Vector}

PCR amplification products of $\mathrm{mGH}$ DNA fragment for giant grouper $(\mathrm{Og}-\mathrm{mGH})$, common carp $(\mathrm{CC}-\mathrm{mGH})$ and giant grouper $(\mathrm{El}-\mathrm{mGH})$ were approximately 576 bp, 579 bp, and 576 bp in length (Figure 1 left), respectively. As predicted and shown in Figure 1 (right), the size of pGEM-T Easy containing mGH DNA fragment (resulting plasmid referred to as pT$\mathrm{mGH}$ ) was bigger than that of pGEM-T Easy (3 kb; T). This indicated that ligation and transformation processes were successful.

In order to isolate mGH DNA fragment from pT-mGH, the plasmid was digested by 2 restriction enzymes as described above. As shown in Figure 2 (left, lane 1), the restriction produced 2 DNA bands, i.e. pGEM-T Easy (3.0 kb) and mGH DNA fragments $(\sim 0.6 \mathrm{~kb})$. The purified $\mathrm{mGH}$ DNA fragment containing 2 restricted sites at the 5' and '3' end, respectively, could then be used to construct protein expression vector. Further, pCold-1 expression vector was also digested by the same restriction enzymes used in the isolation of mGH DNA fragment from $\mathrm{pT}-\mathrm{mGH}$, to prepare a ligation site of mGH DNA fragment into pCold-1. The size of digested pCold-1 (Figure 2, center and lane 3) seemed bigger than the undigested pCold- 1 (Figure 2, center and lane 2), though their size was similar. Visually, different in DNA size was caused by difference of DNA mobility in the electrophoresis gel between the linear digested pCold- 1 and the supercoiled undigested pCold-1. A linear DNA moves slower than the supercoiled, but it faster than an open circular (Li et al., 1991).

Further, the mGH DNA fragment was ligated with the linear pCold- 1 and then transformed into $E$. coli $\mathrm{DH} 5 \alpha$. DNA plasmid of ligation product from three bacterial clones for each $\mathrm{mGH}$ fish was then sequenced to identify the bacterial clones which carry the plasmid containing $\mathrm{mGH}$ DNA sequence similar with the references reported earlier. From the sequencing results (data not shown), one clone bacteria for pCold/Og-mGH, two clones for pCold/El$\mathrm{mGH}$ and $\mathrm{pCold} / \mathrm{Cc}-\mathrm{mGH}$ contained mGH DNA

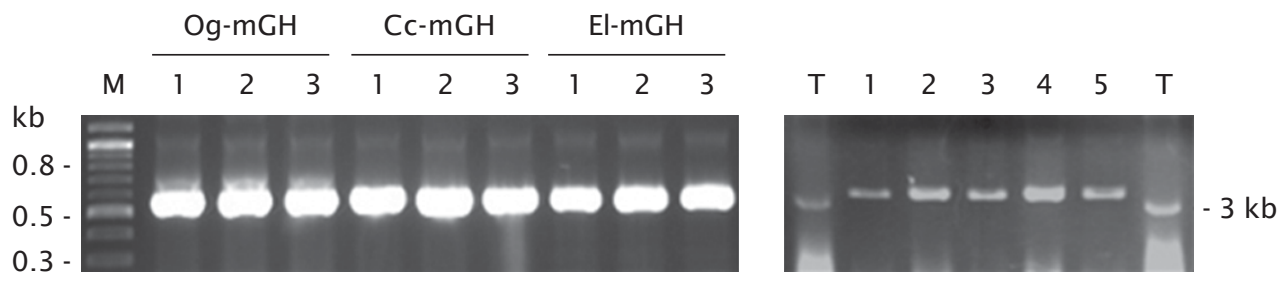

Figure 1. Left: $\mathrm{PCR}$ product of DNA fragment coding for mature $\mathrm{GH}(\mathrm{mGH})$ from giant gouramy $(\mathrm{Og}-\mathrm{mGH})$, common carp $(\mathrm{Cc}-\mathrm{mGH})$ and giant grouper $(\mathrm{El}-\mathrm{mGH})$, and right: cracking the bacterium E. coli DH5 $\alpha$ containing ligation product of pGEM-T Easy (T) and mGH DNA fragment. Lanes 1 through 3 in figure-left and 1 through 5 in figure-right were the number of sample for each fish $\mathrm{GH}$ and bacterial colony, respectively. $M$ was 2-log ladder DNA marker (BioLabs Inc., New England) 

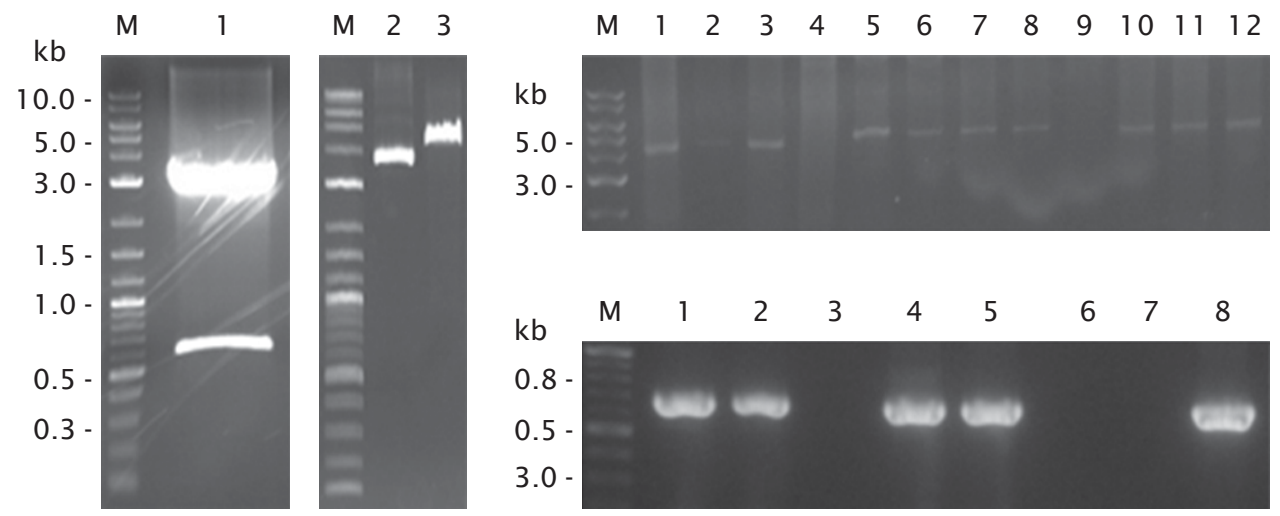

Figure 2. Left: $\mathrm{pT}$-mGH restriction resulted $3.0 \mathrm{~kb}$ pGEM-T Easy (pT) and $\sim 0.6 \mathrm{~kb}$ mGH DNA fragments. Center: supercoiled pCold-1 plasmid (lane 2) and linear digested pCold-1 (lane 3). Right-top: cracking product of E. coli BL2 1 carrying pCold-mGH plasmid; lanes 1 through 12 were the number bacterial colonies. Right-bottom: PCR products in analysis of insert orientation in pCold- 1 vector; lanes 1 through 8 were the number bacterial colonies. M was 2-log ladder DNA marker (BioLabs Inc., New England)

sequence as in the database. Plasmid from those E. coli DH $5 \alpha$ clones was transformed into E. coli BL21 for recombinant protein expression. As shown in Figure 2 (right-top), almost the transformed E. coli BL21 carried the plasmid. The pCold-mGH plasmid was then isolated from the bacteria to verify orientation of DNA ligation using PCR method with pCold forward and $\mathrm{mGH}-\mathrm{R}$ primers. The size of PCR amplification product was about $0.65 \mathrm{~kb}$ consisting of $0.6 \mathrm{~kb}$ mGH DNA and $0.05 \mathrm{~kb}$ of pCold- 1 fragments. Figure 2 (right-below) showed 5 of 8 bacteria clones carrying the pCold-mGH with proper insert orientation. Totally, it was obtained 10 bacterial colonies for $\mathrm{pCold} / \mathrm{Og}-\mathrm{mGH}$, 10 for $p$ Cold/El-mGH and 6 for pCold/Cc-mGH.

\section{Production of Recombinant Protein rGH}

The $\mathrm{rGH}$ protein for giant gouramy $(\mathrm{Og}$ $\mathrm{mGH})$, common carp $(\mathrm{Cc}-\mathrm{mGH})$ and giant grouper (El-mGH) in E. coli BL21 using pCold-1 expression vector successfully produced (Figure 3, showed by arrow head). The predicted size of rGH was about $22 \mathrm{kDa}$, smaller than the size of rGH showed in Figure $3(25 \mathrm{kDa})$. The additional size of $3 \mathrm{kDa}$ was from His-tag, Factor Xa site and multi cloning sites located at the upstream of $\mathrm{GH}$ sequence in the vector. Further, a $200 \mathrm{~mL}$ of liquid culture medium could produce 0.93 grams of bacterial cells containing $\mathrm{rGH}$. Using the software Totallab TL 120,

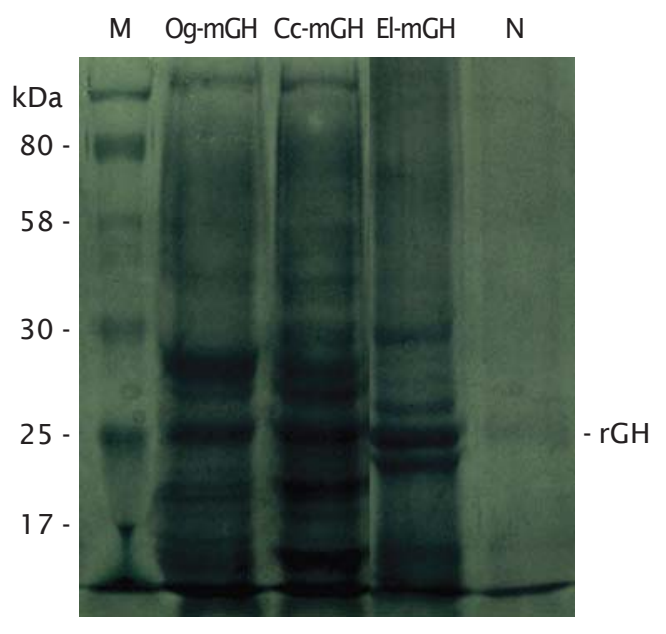

Figure 3. SDS-PAGE of recombinant protein growth hormone $(\mathrm{rGH})$ for giant gouramy $(\mathrm{Og}-\mathrm{mGH})$, common carp $(\mathrm{Cc}-\mathrm{mGH})$ and giant grouper $(\mathrm{El}-\mathrm{mGH})$. rGH protein was showed by the arrow head. M was prestained protein markers (Biolabs) and $\mathrm{N}$ was proteins from E. coli BL21 carrying pCold-1 empty (no mGH DNA insertion)

$\mathrm{rGH}$ production levels of the three fish species were relatively similar and ranged from $8.00 \%$ to $12.04 \%$ of the total protein produced 


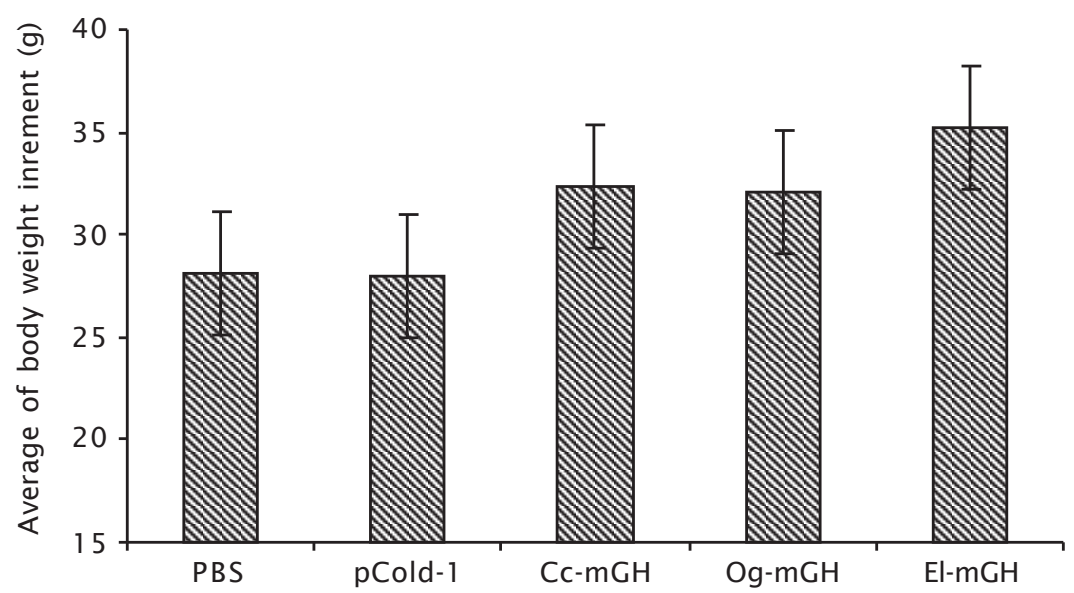

Figure 4. The increment of Nile tilapia body weight ( $\mathrm{g}$ ) after injected with the inclusion bodies containing $\mathrm{rGH}$ from giant gouramy $(\mathrm{Og}-\mathrm{mGH})$, common carp ( $\mathrm{Cc}-\mathrm{mGH})$ and giant grouper $(E /-\mathrm{mGH})$. Inclusion bodies of $1 \mu \mathrm{g}$ per gram Nile tilapia body weight was injected once a week for four weeks, and fish growth was measured every week for two months. PBS: fish injected with phosphate buffer saline, and pCold-1: fish injected with inclusion bodies from bacteria containing pCold-1 empty without insersion of mGH DNA fragment

by $E$. coli $\mathrm{BL} 21$, though other proteins varied. The $\mathrm{rGH}$ production levels obtained in this study were relatively similar with the earlier studies for tuna GH (Sato et al., 1988), tilapia $\mathrm{GH}$ (Rentier-Dulue et al., 1989) and yellowfin progy $\mathrm{GH}$ (Tsai et al., 1995), i.e. 5\%-10\% of total protein. In addition, E. coli BL21 carrying pCold1 empty (without mGH DNA insertion) produced no $\mathrm{rGH}$ and other insoluble proteins as in E. coli BL2 1 carrying pCold-mGH. However, variation in protein production levels in E. coli BL2 1 carrying pCold-mGH and no other insoluble proteins produced in E. coli BL21 carrying pCold-1 empty remained to be elucidated.

\section{Bioactivity of $\mathrm{rGH}$ Protein in Nile tilapia}

The growths of Nile tilapia injected with $\mathrm{rGH}$, protein from bacteria carrying pCold-1 empty, and PBS as control were compared to determine the bioactivity of $\mathrm{rGH}$ protein. As shown in Figure 4, the average increment of fish body weight injected with $\mathrm{rGH}$ was sligtly higher compared with the controls (PBS and protein of pCold- 1 empty injected fish). This indicated that $\mathrm{rGH}$ protein possessed bioactivity in terms of increasing the growth of Nile tilapia as a model. The increment of fish body weight after injected with $\mathrm{rGH}$ of $\mathrm{El}-\mathrm{mGH}$
(20.94\%) was slightly higher than the two other rGHs (18.09\% for the Cc-MGH and $16.99 \%$ for the $\mathrm{Og}-\mathrm{mGH}$ ). Thus, the bioactivity of $\mathrm{El}-\mathrm{mGH}$ in Nile tilapia was higher compared to $\mathrm{Gg}$ - $\mathrm{mGH}$ and $\mathrm{Cc}-\mathrm{mGH}$, while $\mathrm{Gg}-\mathrm{mGH}$ and $\mathrm{Cc}-\mathrm{mGH}$ were relatively similar.

\section{Discussion}

Application of recombinant technology for fish $\mathrm{GH}$ as a strategy to improve the growth has been reported by various researchers (Tsai et al. 1997; Promdonkoy et al. 2004). In this study, as a first step towards growth enhancement of farmed fish species, $\mathrm{rGH}$ of three farmed fish had been produced in E. coli. Expression vector used was pCold-1, while earlier studies were generally used $\mathrm{pET}$ as the expression vector (Sekine et al., 1985; Sato et al., 1988; Tsai et al., 1995). Both expression vectors were induced with IPTG to produce recombinant protein, but pCold- 1 could also be induced using low temperature incubation $\left(15^{\circ} \mathrm{C}\right)$. Production levels of $\mathrm{rGH}$ using pCold- 1 , 8.0\%-12.0\% were comparable to that of studies using other vectors, such as pET; 5.0\%-15.0\% (Sekine et al., 1985; Sato et al., 1988; Tsai et al., 1995). Nucleotide sequences of the three fish mGH used in this study were different; the homology between giant gouramy versus 
giant grouper was $84.93 \%$, giant gouramy versus common carp was $60.73 \%$, and giant grouper versus common carp was $61.61 \%$ ). Thus, variation in $\mathrm{rGH}$ production may be caused by $E$. coli preference to codon sequence in translation process (Seetharam et al., 1988), bacterial culture system, and construction of vector expression used. In addition, variation in fish model used in rGH bioactivity analysis may be also taken into account.

The dose of inclusion bodies containing $\mathrm{rGH}$ injected in the Nile tilapia was the same among the treatments. Growth of $\mathrm{rGH}$-injected Nile tilapia was higher compared to that of noninjected rGH control. Thus, rGH produced in this study was biologically functioned as a growth stimulator. Growth enhancement of El$\mathrm{mGH}$-injected Nile tilapia was slightly higher compared to that of $\mathrm{Gg}$-mGH and $\mathrm{Cc}-\mathrm{mGH}$, while the last two was similar. As shown in Figure 3, number of protein derived from $\mathrm{El}-\mathrm{mGH}$ recombinant bacteria was less than that of $\mathrm{Gg}-\mathrm{mGH}$ and $\mathrm{Cc}$-mGH. Proportion of rGH in El-mGH contained inclusion bodies was higher than that of $\mathrm{Gg}-\mathrm{mGH}$ and $\mathrm{Cc}-\mathrm{mGH}$. Thus, the differences on the growth stimulation of rGH may be resulted from the variation on the actual doses of rGH injected. Injection using a purified rGH needs to be performed to obtain a real bioactivity of the three rGHs.

The delivery method of $\mathrm{rGH}$ applied in this study was injection. This technique might be impractical for farmers. By technical considerations and the efficiency of $\mathrm{rGH}$ application in fish farming, further research needs to be conducted to determine a proper delivery method. Mass delivery method of $\mathrm{rGH}$, such as through supplementation in commercial diet (Moriyama et al., 1993; Tsai et al., 1997; Jeh et al., 1998) and immersion (Moriyama \& Kawauchi, 1990; Moriyama et al., 2008) have been developed. Supplementation of $\mathrm{rGH}$ in the diet of black snapper juvenile improved the growth up to $60 \%$ (Tsai et al., 1997). Immersion of fish juvenile in the medium containing $\mathrm{rGH}$ enhances the growth, such as $43 \%$ in coho salmon and about $60 \%$ in chum salmon (Moriyama \& Kawauchi, 1990). In addition, immersion of Nile tilapia larvae in the water containing rGH-produced Pichia pastoris can drastically enhanced the growth; 171\% (Acosta et al., 2007). In our ongoing study, immersion of giant gouramy larvae in the water containing giant gouramy rGH $(\mathrm{Og}-\mathrm{mGH})$ improved the body weight; almost 2-fold higher compared to the control. Thus, immersion method may be as an effective and suitable way to deliver $\mathrm{rGH}$ to improve farmed fish growth for fish farmers.

\section{CONCLUSIONS}

1. Recombinant growth hormones $(\mathrm{rGH})$ of giant gouramy, common carp and giant grouper have been produced in E. coli.

2. The three rGHs possessed bioactivity in terms of accelerating the growth in Nile tilapia.

\section{ACKNOWLEDGEMENT}

This study was partially supported by the grant of Hibah Kompetensi No.: 219/SP2H/PP/ DP2M/V/2009 from Directorate General of Higher Education, the Ministry of Education.

\section{REFERENCES}

Acosta, J.R., Morales, R., Morales, M., Alonso, M., \& Estrada, M.P. 2007. Pichia pastoris expressing recombinant tilapia growth hormone accelerates the growth of tilapia. Biotechnol. Lett., 29: 1671-1676.

Alimuddin, Octavera, A., Arifin, O.Z., \& Sumantadinata, K. 2008. Characterization of $\beta$-actin promoter from Nile tilapia (Oreochromis niloticus). J. Ris. Akuakultur, 7(2): 113-125. (in Indonesian).

Bolivar, R.B. \& Newkirk, G.F. 2002. Response to within family selection for body weight in Nile tilapia Oreochromis niloticus using a single-trait animal model. Aquaculture, 204: 371-381.

Funkenstein, B. 2006. Production of recombinant hormones and growth factors for use in aquaculture. Bamidgeh, 58(4): 320322.

Jeh, H.S., Kim, C.H., Lee, H.K., \& Han, K. 1998. Recombinant flounder growth hormone from Escherichia coli: overexpression, efficient recovery, and growth-promoting effect on juvenile flounder by oral administration. J. of Biotechnology, 60: 183193.

Kobayashi, S.I., Alimuddin, Morita ,T., Miwa, M., Lu, J., Endo, M., Takeuchi, T., \& Yoshizaki, G. 2007. Transgenic Nile tilapia (Oreochromis niloticus) over-expressing growth hormone show reduced ammonia excretion. Aquaculture, 270: 427-435.

Li, M-X, Yeung, H-W, Pan, L-P, \& Chan, S.I. 1991. Trichosanthin, a potent HIV-1 inhibitor, can 
cleave supercoiled DNA in vitro. Nucleic Acids Research, 19:6,309-6,312.

Moriyama, S. \& Kawauchi, H. 1990. Growth stimulation of juvenile salmonids by immersion in recombinant salmon growth hormone. Aquaculture, 112: 99-106.

Moriyama, S., Yamamoto, H., Sugimoto, S., Abe, T., Hirano, T., \& Kawauchi, H. 1993. Oral administration of recombinant salmon growth hormone to rainbow trout, Oncorhynchus mykiss. Aquaculture, 112: 99-106.

Moriyama, S., Tashiro, K., Furukawa, S., \& Kawauchi, H. 2008. Ability of salmon growth hormone to accelerate somatic growth of juvenile abalone Haliotis discus hannai. Fisheries Science, 74: 860-866.

Mulyadi, D., Alimuddin, Subyako, S., Rustidja, \& Maftuch. 2008. Cloning of growth hormone cDNA from giant grouper (Epinephelus lanceolatus). Presented at "Simposium Nasional Bioteknologi Akuakultur II, 14 August 2008". IPB International Convention Center, Botani Square, Bogor. 28 pp.

Nam, Y.K., Noh, J.K., Cho, Y.S., Cho, H.J., Cho, K.N., Kim, C.G., \& Kim, D.S. 2001. Dramatically accelerate growth and extraordinary gigantism of transgenic mud loach Misgurnus mizolepis. Transgenic Res., 10: 353-362.

Nugroho, E., Alimuddin, Kristanto, A.H., Carman, O., Megawati, N., \& Sumantadinata, K. 2008. Cloning of growth hormone cDNA from giant gouramy (Osphronemus gouramy). J. Ris. Akuakultur, 2: 183-190. (in Indonesian).

Promdonkoy, B., Warit, S., \& Panyim, S. 2004. Production of a biologically active growth hormone from giant catfish (Pangasianodon gigas) in Escherichia coli. Biotechnol. Lett., 26: 649-653.

Rentier-Dulue, F., Swenner, D., Philippart, J.C., L-Hoir, C., Lion, M., Benrubi, O., \& Martial, J.A. 1989. Tilapia growth hormone: molecular cloning of cDNA and expression in Escherichia coli. DNA, 8: 271-278.

Sato, N., Murata, K., Nonaka, M., Sakaguchi, M., Kariya, Y., Hayami, T., Kimura, S., Kimura, A., \& Watanabe, K. 1988. Growth promoting activity of tuna growth hormone and expression of tuna growth hormone cDNA in Escherichia coli. Biotechnol. Appl. Biochem., 10: 385-393.

Seetharam, R., Heeren, R.A., Wong, E.Y., Braford, S.R., Klein, B.K., Aykent, S., Kotts, C.E., Mathis, K.J., Bishop, B.F., Jennings, M.J., Smith, C.E., \& Siegel, N.R. 1988. Mistranslation in IGF-1 during overexpression of the protein in Escherichia coli using a synthetic gene containing low frequency codons. Biochemical and Biophysical Research Communications, 155: 518-523.

Sekine, S., Mizukami, T., Nishi, T., Kuwana, Y., Saito, A., Sato, M., Ito, S., \& Kawauchi, H. 1985. Cloning and expression of cDNA for salmon growth hormone in Escherichia coli. Proc. Natl. Acad. Sci., 82: 4,306-4,310.

Tsai, H., Lin, K., Kuo, J., \& Chen, S. 1995. Highly efficient expression of fish growth hormone by Escherichia coli cells. Appl. Environ. Microbial., 61: 4,1 16-4,1 19.

Tsai, H.J., Hsih, M.H., \& Kuo, J.C. 1997. Escherichia coli produced fish growth hormone as a feed additive to enhance the growth of juvenile black seabream (Acanthopagrus schlegeli). J. Appl. Ichthyol., 13: 78-82. 